\title{
Local experiences with mining royalties, company and the state in the Solomon Islands
}

\section{Gordon Leua Nanau}

\section{(2) OpenEdition \\ 12 Journals}

\section{Electronic version}

URL: http://journals.openedition.org/jso/7089

DOI: $10.4000 /$ jso. 7089

ISSN: $1760-7256$

\section{Publisher}

Société des océanistes

\section{Printed version}

Date of publication: 15 December 2014

Number of pages: $77-92$

ISBN: 978-2-85430-118-2

ISSN: 0300-953x

\section{Electronic reference}

Gordon Leua Nanau, «Local experiences with mining royalties, company and the state in the Solomon Islands ", Journal de la Société des Océanistes [Online], 138-139 | 2014, Online since 15 December 2017, connection on 20 April 2019. URL : http://journals.openedition.org/jso/7089; DOI : 10.4000/jso.7089 


\title{
Local experiences with mining royalties, company and the state in the Solomon Islands
}

by

\author{
Gordon Leua NANAU*
}

\begin{abstract}
Royalties, rents and other material benefits from mining ventures have been of interest to development discussions. These benefits are important to all stakeholders but the first mining agreement in the Solomon Islands only accommodated a tiny percentage of the gross value of gold and silver produced as the mining lease to landowning groups. The questions that led me to the Gold Ridge mine and surrounding communities on Guadalcanal in 2007 and 2010 are: (i) Can royalties from the mine be sustainable agents to improve people's livelihoods? (ii) To what extent have royalty payments, licence fees and rents from mines impacted on local Solomon Islanders' lives? (iii) How do mining agreements and courts of law do or do not safeguard local social capital and the environment? In analysing the data, the processes of negotiating mining agreements; movement and resettlement of people; livelihood and gendered opportunities offered by the mine; and the state's role in the mine are discussed in this paper. Moreover, the paper responds to the three questions above and assesses the sustainability of mining royalties and the role of the modern state and processes in the Solomon Islands mining sector.
\end{abstract}

KEYwORDs: relocation, landowners, livelihoods, royalties, mining

The Gold Ridge ${ }^{1}$ mine project covers a leased area of 32 square kilometres and it also has a Special Prospecting Licence (SPL) area of 132 square

\section{RÉSUMÉ}

Les débats sur le développement se sont intéressés aux royalties, rentes et autres bénéfices matériels issues des opérations minières. Ces bénéfices sont importants pour toutes les parties prenantes mais le premier accord minier aux îles Salomon n'a accordé qu'un pourcentage minime du revenu brut de l'or et de l'argent produits sous forme de rente minière aux propriétaires de la terre. Les questions qui mont amené à mintéresser à la mine Gold Ridge et aux communautés riveraines en 2007 et 2010 sont : (i) Les royalties minières peuvent-elles être des vecteurs durables de l'amélioration des modes de subsistance des populations? (ii) Quelle a été l'influence du paiement de royalties, de droits sur les permis et de rentes minières sur les modes de vie des populations locales des îles Salomon? (iii) Dans quelle mesure les accords miniers et les tribunaux protègent-ils ou non le capital social local et l'environnement? Les données analysées dans cet article permettent de discuter des processus de négociation des accords miniers, des mouvements et réinstallations des populations, du mode de subsistance et des opportunités en termes de genre offertes par la mine et $d u$ rôle de l'État face au secteur minier. En outre, l'article répond aux trois questions posées ci-dessus et évalue la durabilité des royalties minières et les rôles et procédures de l'État moderne dans le secteur minier aux îles Salomon.

MoTS-CLÉs : réinstallation, propriétaires fonciers, modes de subsistance, royalties, mine

kilometres on the island of Guadalcanal (ASG, 2007: 4). It commenced production in October 1996 until June 2000 when the mine operators

1. Primary materials used in this paper are from the author's research work among the Gold Ridge and downstream communities since 2007 and subsequent visits after that. I thank the leaders and community members for their support and frank discussions on these trips.

* Lecturer in Government, Development and International Affairs, University of the South Pacific, Suva, Fiji. gordon. nanau@usp.ac.fj 
abandoned operations due to social tensions between indigenous Guadalcanal people and Malaita settlers (Nanau, 2008). The Asia Miner reported that in the first 22 months the mine was in operation:

«[...] [it] produced 210,000 ounces of gold and was the source of $30 \%$ of the Solomon Islands GDP.» (Asia Miner, 2007)

The mine, the first in the country, anticipated losses to homes, spaces, environment and livelihoods and this necessitated the need to negotiate royalty and land rents and other compensation arrangements. Such negotiations take time and agreements initially reached are often amended to suit prevailing circumstances. Manegulai ${ }^{2}$ (pers. com., 3 July 2007) indicated that it took about 30 years of prospecting and 17 years of negotiations to establish the Gold Ridge mine. $\mathrm{He}$ conceded that to negotiate an agreement that could be regarded well by all stakeholders is very difficult. For Gold Ridge landowners, it was more of a trial and error over 17 years and the post tension Subsidiary Agreement (2006) attests to these continuous demands for improvements (see GRML and GRCLAC, 2006). It should be stated at this juncture that the people of the Gold ridge area have had previous experience of artisanal mining and are therefore conscious of the value of gold. As such their understanding of industrial mining is influenced by that experience. Moreover, those living downstream have never had the experience of dealing with mining pollution in the past and that experience also influenced their understanding of industrial mining.

\section{Methodology}

The methodology used in this research is more a constructivist/critical realist epistemology. One aspect of this position is that knowledge claims are always socially situated rather than universalistic (Gegeo and Watson-Gegeo, 2002). Critical realists argue that people possess knowledge by being in the world with elements of a predisposed historical, path dependent framework. As Proctor (1998) puts it:

«[k]nowledge to critical realists is neither wholly objective nor subjective but is in fact the result of interaction between subject and object. [...] the truth contents of ideas can be compared on a relative basis: some (social) explanations are more adequate representations of reality than others, though all are, by virtue of the dialectic (subject-subject) nature of knowledge, always "partial truths".» (Proctor, 1998: 361)
In this research, the focus is primarily on the experiences of landowning groups and the Solomon Islands Government. Official company documents and agreements are also consulted to indicate the company position.

A variety of interrelated methods were used to access information from the different actors in the natural resources sector. The first and most used method is individual face to face interview. Appointments were made with respondents and with the help of lists of questions specifically targeting three different groups in the landowning communities, interviews were conducted with individuals. In a number of situations, individual interviews were not possible so focus group discussions or workshops were carried out to gauge group views. Such focus group discussions were held separately for males, females, youths and community leaders. Apart from interviews and focus group discussions, observations and talanoa or tok stori were relied upon to verify and confirm or disregard information obtained in the interviews and focus group discussions. Talanoa (tok stori in Melanesian pidgin) according to Vaioleti:

«[...] can be referred to as a conversation, a talk, an exchange of ideas or thinking, whether formal or informal. It is almost always carried out face-to- face.» (Vaioleti 2006: 23)

These conversations also produced rich information used to verify materials provided by other informants.

\section{Historical and Political Context of the Study}

Before venturing into the experiences of landowners with the state, state institutions and company, it is important to briefly contextualise the history and political context in which the mine was established. Some accounts attributed the name of the country, Solomon Islands, from a gold nugget that the first European to visit the Solomon Islands, Alvaro de Mendana, picked from one of the river's mouths along the Guadalcanal coast. He called them the Solomon Islands in "the mistaken hope of mineral riches matching those of the biblical king» (Johnson and Powles, 2012: 140). Of course this is a contentious piece of history but the point is that, interest in gold and mineral deposits in the Solomon Islands started way back in those very early days of contacts with the outside world. The declaration of Solomon Islands as a British Protectorate in 1893 gave way the opening up of the islands that are now called Solomon Islands to the outside world. Solomon Islanders

2. Pseudonyms are used in place of real names as part of a total ethical approach used by this research. 
were introduced to the outsids world through the labour tradt (black birding), World War I] experiences and the introductior of waged labour through planta. tion development (see Bennett 1987). The movement of people between islands in response tc plantation and urban administrative centres continued to increas even after flag independence.

The Protectorate also introduced modern laws based on the British laws. Prominent amon these were laws relating to land Land titling and the possibility of leasing land for «development" activity was a feature of the modern tenure, something totally different from traditional lanc tenure that is based on commu. nal ownership. A controversia regulation called the «Solomor Islands Wasteland Regulation> saw the alienation of huge area: on many islands to plantation owners and other busines: people. A bulk of these is founc on Guadalcanal where huge coco. nut plantations were established The aftermath of World War I] also saw the shift of the government's headquarters from Tulagi

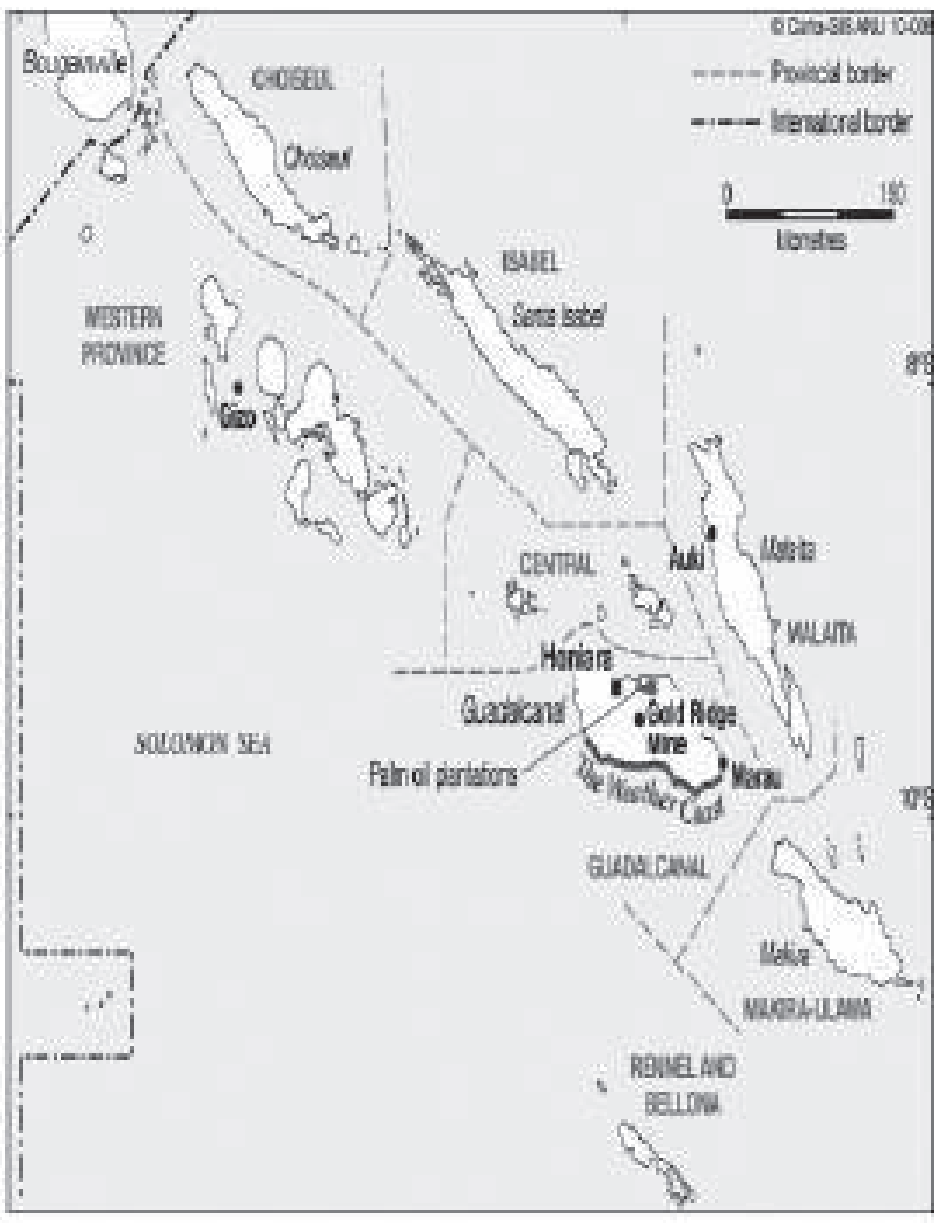

FIgURE 1. - Map of Solomon Islands (source: SSGM, ANU, 2014) in the Central Islands group to

Honiara on Guadalcanal. Urban migration and the movement of people from other islands to Guadalcanal were exacerbated and this brings with it all the social and economic ills of modern society like crimes, poverty and disputes over land. The indigenous people of Guadalcanal also felt exploited by the state because of the assumption that they gave more than the other provinces in terms of revenue from their land and resources. Unfortunately, they felt that provinces with fewer contributions to the national economy are benefitting more from Guadalcanal resources and employment opportunities created there. Moreover, migrants allegedly failed to respect the traditions and cultures of the indigenous people of Guadalcanal and have settled illegally on customary land owned by Guadalcanal tribes and clans. This fear of the «outsider» is also discussed by Filer (1990: 7) in the case of the Bougainville copper mine and is therefore not peculiar to Guadalcanal.

These frustrations and feeling of being exploited were demonstrated through various peaceful petitions and demonstration by Guadalcanal people. The first one was held in 1978 just before independence (Guadalcanal Provincial Council, 1978). The state responded and promised to the address their concern. However, ten years down the road in 1988, Guadalcanal people again petitioned the state on their concerns after multiple murders by settlers in a Guadalcanal village. This time, one item prominent on the agenda is the need for more autonomy by provinces to determine their own destinies by benefiting more from their resources (Gatu, 1988). The government received the petition and again promised to address the issues of concern. Nothing really eventuated and another ten years on, another set of demands was submitted to the state by the Guadalcanal Provincial Assembly after another murder of a Guadalcanal woman (Guadalcanal Provincial Assembly, 1998). It was alleged that the petition triggered anger and resentment in some Guadalcanal youths who formed a militant group, the Guadalcanal Revolutionary Army (GRA) later called the Isatabu Freedom Movement (IFM) to harass and evict migrant settlements, especially from the neighbouring island of Malaita, out of rural Guadalcanal, from plantations and other establishments on the island. The settler population from Malaita responded to the intimidation and harassments by forming a counter militia force, the Malaita Eagle Force (MEF). With the help of some members of the Police Force, they 
removed arms from the national armoury and retaliated. An estimated 200 people were killed and more than 20,000 displaced in the conflict. Several peace agreements and reconciliations failed to broker sustainable peace. The Townsville Peace Agreement (TPA) of 2000 (see sIg et al., 2001) brought an end to overt fighting but it did not stop criminal activities, thus the intervention by the Pacific Islands Forum sanctioned Regional Assistance Mission to Solomon Islands (RAMsI) in 2003 (see Carter, 2006).

The historical, political and cultural issues described here would explain the complex situation in which the Gold Ridge mine was established. Moreover, it explains the relationship between the state, landowners and company and the challenges such a relationship entail. The fieldwork was carried out in a post conflict society where huge plantations, mining and other industries on Guadalcanal and the Solomon Islands more generally were struggling to be reopened. The Gold Ridge Mine was closed in 2000 after police officers moved out of the mine site and militants took control of it and looted/destroyed its facilities. The same could be said for the asset of the Solomon Islands Plantations Limited (SIPL). In this instance, the state leased customary land from custom owners and subleased these mine and plantations lands to companies. The state in most of these undertakings is a middle man instead of it being the driver of such developments. The next section looks at the mining agreement, how wealth is redistributed by local landowning groups, and how landowners perceive the role of the state.

\section{Negotiating the Mining Agreement}

All issues involving royalties and company activities are catered for mostly under the Mines and Minerals Act, the Land and Titles Act, environmental legislations and the Mines and Minerals (Royalty) Regulations (sIG, 2011). As Gold Ridge lease is on customary land, negotiations had to involve the Guadalcanal Provincial Government (GPG), the Commissioner of Lands (CoL) and Solomon Islands Government (sIG), Company, originally the Ross Mining Company Limited, later Allied Gold and now Santa Barbara (St Barbara Limited, 2014). The customary land owners and people of Gold Ridge formed a Charitable Organisation, the Gold Ridge Landowners Council (GRLC) to represent them in these negotiations (GRCLAC, 2006), a process of representation but exclusion of the masses. They were therefore required to institutionalise their local structures and leadership to cater for this new undertaking. The mine ultimately led to the establishment of the Malango and Vulolo House of Chiefs with a constitution that empowers the bigmen $^{3}$ to negotiate or instigate protests on development activities in Central Guadalcanal (Malango House of Chiefs, 2004).

Negotiators usually try to derive maximum benefits from the mine's revenue. New local organisations and structures emerged in response to such expectations from the mine. For example, the mine resulted in the increase in the number of tribes from around five in preroyalty period to sixteen in response to the need to redistribute royalties and other benefits. What were only clans and «sub-clans» became separate tribes in the formal agreement, possibly confusing the kastom ${ }^{4}$ bases of lineages in that particular area. The sixteen «tribes» that became parties to various agreements are Kaokao, Kaipalipali, Roha, Chavuchavu, Lasi, Charana, Chacha, Sarahi, Salasivo, Halisia, Soroboilo, Sobaha, Sutahuri, Rausere, Vatuviti, Koenihao and Kolobisi (Gold Ridge Mine Agreement, 1996: 14)

Trustees become important individuals and councillors are voted in to the GRLC (mostly based on seniority or literacy levels) to negotiate on behalf of the local wantok $k^{5}$ groups. The bigmen therefore become leaders through elections and not necessarily based on kastom merits. The only individuals who became automatic members of GRLC were five Principal Landowners. The educated and articulate members of wantok groups are elected into GRLC. They become trustees entrusted to control royalty payments and decision making on revenue redistribution for their own «tribes». A landowners' council was established with elected members every three years (GRLCAC, 1996: 5)

A youth workshop conducted for this research in Obo Obo village reported that council members are responsible for negotiating with the company. When asked about their understanding of lands leased to company, one respondent indicated that:

«only the Councillors knew about such issues. We youths do not know anything about these. To give an example, Mr. Kulamuloki is a council representative in our village but for some of us, our tribal representatives live far from us.» (Obo Obo Youths, 5 July 2007)

thus the difficulty of getting accurate information. A men's group at Obo Obo also shared the same sentiment saying that:

3. Bigmen is a term that refers to respected leaders of specific family groups and communities.

4. Kastom refers to local knowledge systems, ways of doing things and political organisation.

5. The term wantok in this context refers to blood members of an extended family, clan or tribe. 
"[they] vote representatives into the Gold Ridge Landowners Council (GRLC). These councillors should report back to members of the tribes. Unfortunately, some representatives in the GRLC never report back to their tribes or villages. One man make decisions in Council on behalf of say 5,000+ people.» (Obo Obo Men, 4 July 2007)

Tribe members nevertheless are empowered by the GRLC constitution and could remove their representatives before the three years lapse although no such removals have yet been reported.

\section{The mining agreement and wealth redistribution}

The Gold Ridge Mine Agreement 1996 laid out clearly how royalty, compensations and related matters are to be paid to landowners and the state. Section 6.1 of the Agreement ensured that the company pays $1.5 \%$ of the gross value of gold and silver produced from the mine as the mining lease into a Mining Royalty Special Fund (1996: 7). Eighty percent (80\%) of this will be paid to the 16 groups with registered interest on the leased area and 20\% into a Guadalcanal Province Royalty Special Fund after it is subjected to a $7.5 \%$ government withholding tax. A specific regulation for the Gold Ridge Mine royalties was passed and gazetted in 2011 (sIG, 2011). A breakdown of how such royalties ( $80 \%$ of $1.5 \%$ ) are to be paid to the respective "tribes» of Gold Ridge area is listed below.

This research uncovered how benefactors of such royalty payments use royalty benefits. Manegulai, explained that his tribe received approximately SI $\$ 200,000$ per payment while the other smaller groups receive at least SI $\$ 10,000$ per royalty payment (pers. com., 3 July 2007). It should be pointed out that agreements for the mining campsite and the tailings dam are different from the mining lease agreement which is the focus of this paper.

From the various workshops organised with the landowners, their stories revealed that they only benefitted from quarterly lease agreement payments paid by the company. A member of the Chacha tribe illustrated how far such monies are redistributed at the local level. His tribe receives SI $\$ 12,000$ per payment for a group of around twelve families. He claimed that:

«[...] [they] have 12 passbook accounts which mean that we deposit SI\$1,000 per passbook. It depends on the families whether or not they redistribute their shares further to distant relatives.» (Men's Group, 4 July 2007)

As most households in the area are headed by males, distribution of royalties to female mem-

\begin{tabular}{lc}
\hline $\begin{array}{c}\text { Gold Ridge } \\
\text { Landowning Tribe/Line }\end{array}$ & $\begin{array}{c}\text { Percentage of } \\
\text { Royalty Received }\end{array}$ \\
\hline 1. Rausere & $36.500 \%$ \\
2. Charana & $6.300 \%$ \\
3. Kaokao & $6.300 \%$ \\
4. Roha & $6.300 \%$ \\
5. Sutahuri & $6.300 \%$ \\
6. Vatuviti & $6.300 \%$ \\
7. Halisia & $6.200 \%$ \\
8. Soroboilo & $6.200 \%$ \\
9. Chacha & $5.000 \%$ \\
10. Sabaha & $3.925 \%$ \\
11. Salasivo & $3.225 \%$ \\
12. Chavuchavu & $2.500 \%$ \\
13. Kaipalipali & $1.325 \%$ \\
14. Koenihao & $1.225 \%$ \\
15. Lasi & $1.200 \%$ \\
16. Sarahi & $1.200 \%$ \\
Total & $100.000 \%$ \\
\hline
\end{tabular}

Table 1. - Gold Ridge Landowners and Royalty Shares (Source: Gold Ridge Mine Agreement 1996)

bers of tribes and individual households is dependent on the decisions of fathers, brothers and uncles. The influences of subsistence living and cultural exchanges impacted very much on how these people redistribute mineral royalties. There is very little indication of savings or reinvestment. Money is shared as soon as it is withdrawn from the bank by trustees (Youths, 5 July 2007). The role of the state in this arena is very limited facilitating payments from company to landowning groups as per the mining agreement. The state in this instance would only support in terms of organised workshops to assist landowners and other stakeholders identify common pitfalls to be addressed. In one of these workshops in 2013, the Special Secretary to the Prime Minister highlighted that:

«[...] the Government has seen that landowners of Goldridge mining did not invest their royalties in sustainable enterprise after receiving it.» (Osifelo, 2013)

After the country's civil uprisings from 1998 to 2003 , efforts to reopen the mine also instigated compensation claims from various groups. People asked to be compensated by company and the state for damages caused by Ross Mining, outstanding commitments by the previous mining company and government, and assistance to deliver public services and build amenities in the area. Prior to 2000, the Gold Ridge Mining Limited (GRML), a subsidiary of Ross 
Mining NL owned the mine. During the period of unrest and tension, ownership was passed to the political risk insurer, American Home Assurance Company (AHAC) and Australian Solomon Gold (ASG) took over the company in 2004 after an international tender (ASG, 2008: 8). Allied Gold bid for and compulsory acquired ASG in October 2009 and is therefore the $100 \%$ owner of Gold Ridge in 2010. In September 2012, St Barbara Limited again took over from Allied Gold and is currently operating the mine (see St Barbara Limited, 2014). During the period leading up to the reopening of the mine, landowners insisted on the company and the state to meet financial and service needs of people in the area. This is regarded as a measure of company commitment to operate a mutually beneficial mine and to appease disagreements among them and other parties. The signing of a subsidiary agreement in May 2006 attested to additional claims for benefits.

Quite obvious is the perception that the state is another external entity. The state is not seen as an entity safeguarding the interests of local landowners communities but an institution more supportive of company interests. Mr. Kulamuloki, a member of the GRLC made a telling statement when he lamented that:

«the state should be the referee in the game between the mining company and the resource owners. In this case, the state also wants to score the ball!» (pers. com., 3 July 2007)

Various community and local level organisations looking after the affairs of Obo Obo community and surrounding villages like Bemuta submitted demands in the form of wish lists to both company and the state as urges to reopen the mine around 2004 and 2005 were becoming apparent. The Obo Obo Community for instance negotiated and signed a MOU with ASG for the company to retrieve its equipment rescued by the villagers before and after the Guadalcanal tensions (see Bemuta Community Relocation Committee, 2006). GRML and ASG Limited therefore committed themselves to support various projects in the village including the restoration of a water supply, repair and maintenance of roads, support in constructing a kindergarten, church and community hall buildings and other support to women groups and income generating projects (MOU signed on $9^{\text {th }}$ June 2005). A recent example was made by Chovohio Midstream Association members in April 2013 for St Barbara to compensate them for activities negatively impacting on the environment (water) and livelihood (sto, April 2013). These mous do not have time lines and are not legally binding but a form of negotiated compensation (see Filer and Macintyre, 2006; Banks, 2008). The role of the state in such arrangements is usually to facilitate such meetings where understandings are reached between landowners and the company. In certain instances, the MOUs are only an understanding between the company and communities and nothing to do with the state. It is when such mous are not adhered to by the company or violence is eminent that landowners usually request the state to intervene with the hope of forcing the company to meet its agreed obligations to communities.

At times, landowning groups make submissions to the state with the hope that they be listened to because of the contribution they make to state revenues from mineral resources on their land. An example was the submission by the Gold Ridge Community and GRCLAC to the Solomon Islands Government in April 2007. Some demands in this particular submission included the transfer to the investment arm, GIL the perpetual title of the Lunga land on which the first relocation village was situated; that SIG and GRML to build houses for those displaced by the mine in two new locations of Kovalei and Ravua; the quick payment of land premium by government; the closure of water sources for the mining plant as it was not paid for; the quick transfer of prime site land in Honiara as per previous agreements and waiver of SI\$42,000 stamp duty fee; compensation for loss of crops; immediate payment for lost property to people of Malango and Vulolo Wards as a consequence of the tensions; and, that government give a loan guarantee to Gold Ridge Investment Limited (GIL) of up to SI\$6 million (GRCLAC, 2007: 1-10).

Apart from the establishment of GIL which is yet to undertake business activities, most requests and demands to the company and the state are unsustainable in the long run. The establishment of the mine also comes with increased expectations that could hardly be met through royalties and these gave rise to more demands and compensation claims. These resulted in the signing of several separate agreement and mous between the landowners and other stakeholder in the Gold Ridge mine apart from the main mining agreement, a divide and rule strategy by the mining company. This is not peculiar to Gold Ridge as it was also the case in Australia and Papua New Guinea (O'Faircheallaigh, 2008: 37). At times this result in companies gaining tax relief to provide basic services to areas around their operation sites (Callick, 2005: 183). These may include building health centres and schools, maintaining roads and providing scholarships. Since the negotiations and demands mostly relate to environment and livelihood concerns, it is important to have a discussion on how modern law and local kastom do not usually complement each other. 


\section{Modern laws and local kastom discrepancies}

The idea of trusteeship contradicts local understandings of collective land ownership (Nanau, 2008). Collective ownership on Guadalcanal is a complex concept whereby certain clans (commonly known as mamata) are custodians of land used by themselves and other members of the community. The mamata, an off shoot of the Kema (tribe) has a lot (but not ultimate) influence over the overall use of the land. Members of the same mamata have equal rights over the land but they have specific areas where they make their food gardens or homes that are respected as primarily owned by distinct families of the same mamata. In a way, there are areas with the mamata land those individual and extended families (still collectively) of the same clan and their associates (children, marriage relatives, etc.) have «respected" control over. Other members of the clan simply have to ask before using or getting things out of that area. Indeed there are bundles of rights over land but control over land is culturally a collective effort by members of the mamata (see Nanau, 2011). When giving titles to land, trustees sometimes behave like sole owners of tribal land and shares. Allen state:

"While both state law and customary practice dictate that trustees are obliged to share royalties and rents with other members of their landowning groups, in practice they have not done so.» (2012: 308)

Once communal land is registered under the trusteeship of individuals, disputes within these local wantok groups can be very difficult to sort. This is because the written agreements and titles are extremely difficult to challenge under laws imposed by modern states.

These laws do not recognise secondary rights by clan members to cultivate, hunt, collection of building materials, other common properties, and even historic rights in those pieces of land (O'Faircheallaigh, 2008: 39). Even maternal and paternal rights and privileges to use land are not recognised by modern state laws. Modern laws and court systems differentiate between primary and secondary rights while it is not that clear cut in local understandings of landownership. Maenu'u (1994) and Filer (2006) provide somewhat opposing views that could be the basis for further investigations into the communal versus individual land ownership perceptions in Melanesia. Suffice to say that in the Solomon Islands, there is communal ownership of land but that the landowning tribes also respect individual members' ownership of properties built on or planted on communal lands. Extractive industries such as logging and mining complicate ownership and use of land in communities as the two external entities, the state and company become part of the equation. The notion of the «enclave economy» (see Le Meur, Ballard et al., 2013) is fitting in where there is community/ state/company interactions.

A court case against Ross Mining and Others by John Maningelea and Others (1997) will demonstrate this incompatibility. Part of the claims in this particular case, Maningelea and others alleged that:

«[...] the said Agreement [Gold Ridge Mine Agreement] contained no enforceable rights; that the compensation there contained was illusory (paragraph 12); that false representations had been made (paras. 15 and 16); allegations of unconstitutionality (paras.14-20); and failure to compensate secondary right holders (para. 21).» (High Court of Solomon Islands, 1997b)

Setting aside all the technical arguments pertaining to this case, the Judge made the following statements in his ruling:

"As to the rights of the plaintiffs to challenge the validity of the compensation Agreement, it is trite law that only parties to the Compensation Agreement can seek to enforce the terms of such an Agreement or to challenge its validity. It is clear that the Plaintiffs are not parties to the said Agreement. All that they have alleged in their Statement of Claim is that they have customary interests or rights over the said Land. At the most, this amounts to a mere assertion because in contrast, the Second Defendant relies on the SubLeases granted to it by the Commissioner of Lands on or about $12^{\text {th }}$ March 1997. The Commissioner of Lands in turn had acquired leases from the registered joint owners of the 25 perpetual estates of the said Land. The Plaintiffs therefore face an uphill and formidable task to challenge the registered rights and interest of those joint owners. The mere fact that they allege they have an interest or right over the said land does not entitle them per se to challenge the validity of the Agreement. They will have to challenge the title of the joint owners of the said Land first under the provisions of the Land and Titles Act, and only if successful, can they in turn challenge the validity of the Compensation Agreement. I find with respect this claim of the Plaintiff as disclosing no reasonable cause of action and should be dismissed.» (High Court of Solomon Islands, 1997b: 2)

The critical point to learn from this court challenge is the great difficulty of reconciling modern land law and local people's understandings of landownership and use in Solomon Islands. The written agreement and technicalities of modern laws on land safeguard private property and investment promoted by transnational corporations (TNCs) and in the process rural livelihoods and subsistence become negligible concerns. It is in such situation where the impositions of the educated and literate local population on those still clinging on to local understandings of land that brew hatred and tension in countries like 


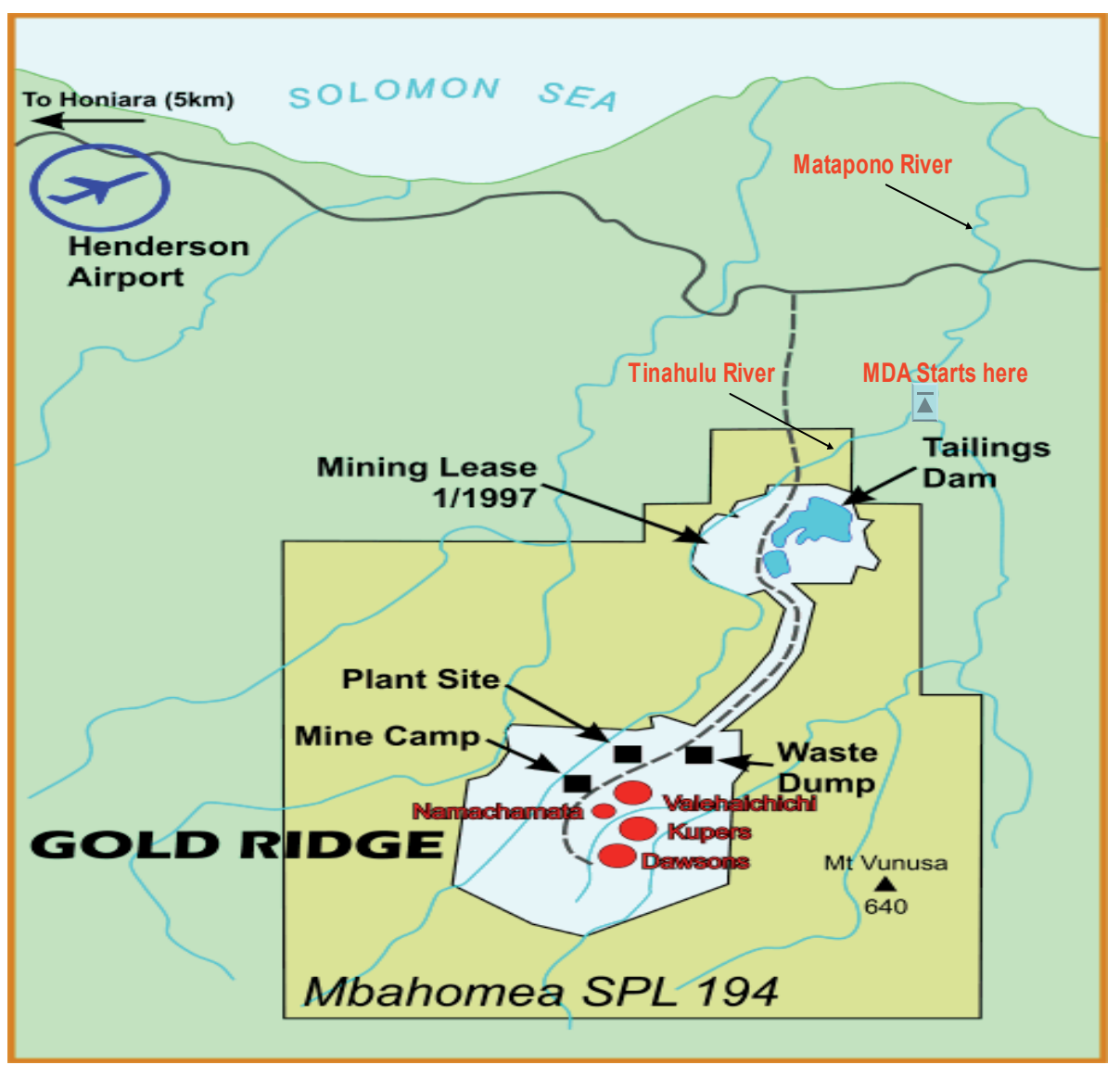

FIgURE 2. - Gold Ridge Mine on Guadalcanal (adapted from ASG Limited, 2007)

the Solomon Islands. In many instances, new property laws and institutions contradict local people's ways of seeing things and frustrations turn into violent disputes and conflicts. It is in situations where people can no longer stand up to safeguard their local understandings and rights to land and what they genuinely believe that result in tensions and conflicts. It should also be emphasized that because modern laws are written and local stories of landownership in local communities are orally kept, knowledge based on the written word always have the upper hand.

Apart from the confusions where two different sets of perceiving land converge, there are also disagreements between land owners and company on the provisions of the original mining agreement, royalty and compensation payments and on the adverse impacts of mining on the environment. Concern for environmental pollution and negative impacts on livelihoods of people living along the Matapono River and the tailings dam gave way to the formation of the Matapono Downstream Association (MDA). Membership and influence of MDA start where the two rivers meet as shown in Figure 2 below.
The MDA's stance is that GRML poses health and environmental risks to their livelihoods. According to the men of Tumurora, MDA is within the mining zone and is a legal entity looking after the concerns of Tumurora and Pituloki communities. They insisted that these communities did not receive support from the mining company despite the potential irreversible impacts the mine has on their river and food gardening areas. The Association was established to secure compensation for the damages the mine has already done to their river. They indicated that road maintenance was the only thing the mining company assisted the community with (Tumurora men, 13 May 2007). MDA was thus established as an environmental concern body monitoring the effects of the mine downstream while also acting as a lobbyist for compensation on environmental degradation and effects on livelihoods.

Apart from the above 1998 civil case, three other civil cases were brought against the mining company. These were civil case 59 in 1997 known as the "Gatu proceedings»; 60 in 1997 referenced as the "Roni/Thughuvoda proceedings"; and 169 of 1997 referenced as the "Saki proceedings». The case by Samuel Saki and 
others raised among other things the threat of waste and other materials discharged from the mining operations into the Matapono River (High Court of Solomon Islands, 1997c). The case by Roni and Thughuvoda was aimed at seeking additional financial benefits and compensations from the proceeds of the mine beyond what was signed in the Gold Ridge Mine agreement of 1996 (High Court of Solomon Islands, 1997a). Gatu's case focuses more on pressuring the Gold Ridge Mining Company to obtain electricity supply from the Lunga Hydro Power Consortium (High Court of Solomon Islands, 1998), another Australian firm. As they turned out, Gatu's case was dismissed on $17^{\text {th }}$ September 1998, Roni/Tghughuvoda proceedings were discontinued $3^{\text {rd }}$ October 1997 as they entered into written Agreements (known as «Deed of Release») with Ross Mining (Solomon Islands) Limited and a later application to revive these proceedings were dismissed by the High Court (High Court of Solomon Islands, 1998).

The Australian Law Firm, Slater and Gordon ended up battling it out with Ross Mining (sI) Limited and Gold Ridge Mining Limited (High Court of Solomon Islands, 1998). These were two Australian companies with interests in Solomon Islands. A bigman of the major landowning group (Rausere) of the mining lease joined the opposition spearheaded by Slater and Gordon until he decided to drop the case and allow the mine to continue. The bigman withdrew his support to Slater and Gordon's case after revelations that his counterpart had used up substantial amounts of money for himself. He also withdrew the second case with allegations that the same person obtained more money from the foreign company (Nanau, 2008). The important point to make here is that interests of foreign and international companies are sometimes played out at the local level using local trustees and bigmen as exemplified here. Elements of global and local elite interests are sometimes aligned in company undertakings giving rise to vulnerability, insecurity and intra-wantok instability at the local level. I have dealt with this causality between the local/global coalitions and local people's vulnerabilities in detail elsewhere (see Nanau, 2008, 2011).

\section{Environment and livelihood risks}

The nature of mining gave rise to environmental concerns both in the area and beyond. The Saki case above was one of the legal challenges against the mining company when it started operations in 1996. The fear was that harmful discharges to the Matapono River could affect the livelihoods of the many people downstream who depended on the river for their daily use and those along the coast as they use the sea for food on a daily basis. Dunkerley and Hallam (1997: 7) earlier draw attention to the possibility of tailings entering the large rivers through small tributary streams. The Saki case application was on the principles of 'nuisance and trespass'. They highlighted that because of their residence along and use of the Matapono River, the mine activities will discharge materials that are dangerous and harmful to them. A closer look at Figure 1 above would explain the vulnerability and insecurity sentiments as overflows from tailings and waste dams and actual mining upland could potentially find their way through tributaries and into the main Tinahulu and Matapono rivers. The High Court felt that there was no strong evidence to support this claim. In his ruling, the Judge, himself a Solomon Islander said:

"With respect, there is little that can be said in support of the allegations that waste materials from the mining operation will be discharged into Matepono River. The plaintiffs have failed to show a strong probability that the mining operations will cause imminent and substantial damage to the Plaintiffs property, business or livelihood. Whilst a fear might exist in the mind of the plaintiffs, this has not been backed up with the necessary causative link between the alleged wrongful behaviour of the defendant and the harm or damage to the Plaintiffs.» (High Court of Solomon Islands, 1997c)

The requirement by the legal system to come up with scientific evidence to support claims by ordinary people who may have concerns for health and livelihoods in such situations is remarkable. It would seem that the legal system and company work together and are on the same line of thought contrary to the precautionary principle that state institutions are to protect the rights and concerns its citizens. Tensions emerge in such situations as the anxieties of people and their livelihoods are not accommodated.

Despite these unsuccessful legal bids to seek additional benefits or redress from the legal system, evidence later showed that the mining company was not fault proof as earlier indicated. A leakage or overflow from the pipes from the tailings dam to the water reticulation pool found its way to the Tinahulu River (this joins with the Matapono River) and fish died in great numbers in the late 1990s. Indeed an earlier environmental assessment by researchers from Monash University (Dunkerley and Hallam, 1997) had indicated these dangers in their report. Their summary is that the high rainfall experienced in the Solomon Islands over recent years coupled with the mine's location in a deeply dissected, high altitude site meant that three major problems are highly likely. They are: (i) overburden run off into the river systems, (ii) Potential overflow 
from the tailings dams, and (ii) Potential pollution of the river system with cyanide following heavy rains (Dunkerley and Hallam, 1997: 2).

Environmental concerns are huge for people especially those living along the Matapono river. At Tumurora, stories of hazards from the mine always emerge in village workshops, especially when discussing threats to downstream communities. A piece of evidence they pointed to was the increased sedimentation of the river. Erosions due to loosening soil by mining up at Gold Ridge, resulted in increased sedimentation and the diversion of flood waters into their food gardens and cocoa plantations. The consequence is damage especially to cocoa trees and food gardens along the river beds. As Figure 3 below show, the increased sedimentation subsequently diverged flood water into cocoa and coconut plantations and after months of water table remaining high, vast areas of cocoa trees were destroyed, affecting one of the most important sources of income for many families at Tumurora.

These were reported to the Ministries responsible for mines and environment and they did visit and carried out assessments. Evidence on the ground showed that sedimentation is a real threat and other environmental concerns raised are from people's actual experiences. If what is seen can be regarded as evidence and stories of people who experienced these changes can be accepted, then environmental concerns and threats are real and related to company activity upstream. Citi- zens in these communities rely on the state and its agents to assist them convey to the company the disruptions to livelihood and ultimately request for compensation on their behalf.

A recent cyanide leakage from a broken pipe in late May 2011 was kept a secret by the mining company until a local newspaper reported it. The spillage was alleged to continue for more than 5 hours and the effects to humans and environment are yet to be determined by responsible authorities (Namosuaia, 2011). A former Premier of Guadalcanal Province and leader of MDA commented:

«our people demand Gold Ridge Mining Limited (GRML) an explanation as to why our communities were not informed and being consulted about the incident when it first occurred.» (Namosuaia, 2011)

Throughout 2012 and 2013, many more complaints on the company's disregard for the environment were aired. This was not helped by the rapid change of hands in company ownership as St Barbara Ltd acquired Allied Gold in September 2012. Secrecy, opacity and monopoly of information also give us an idea of the relationship between people, company and the state. The company has monopoly over information about the company activities and deficiencies.

In April 2013, St Barbara applied for a de-watering licence to release the tailings dam water into the river with the justification that the unusual

Figure 3. - Impact of Matapono River sedimentation on cocoa plantations (2007, picture Gordon Leua Nanau)

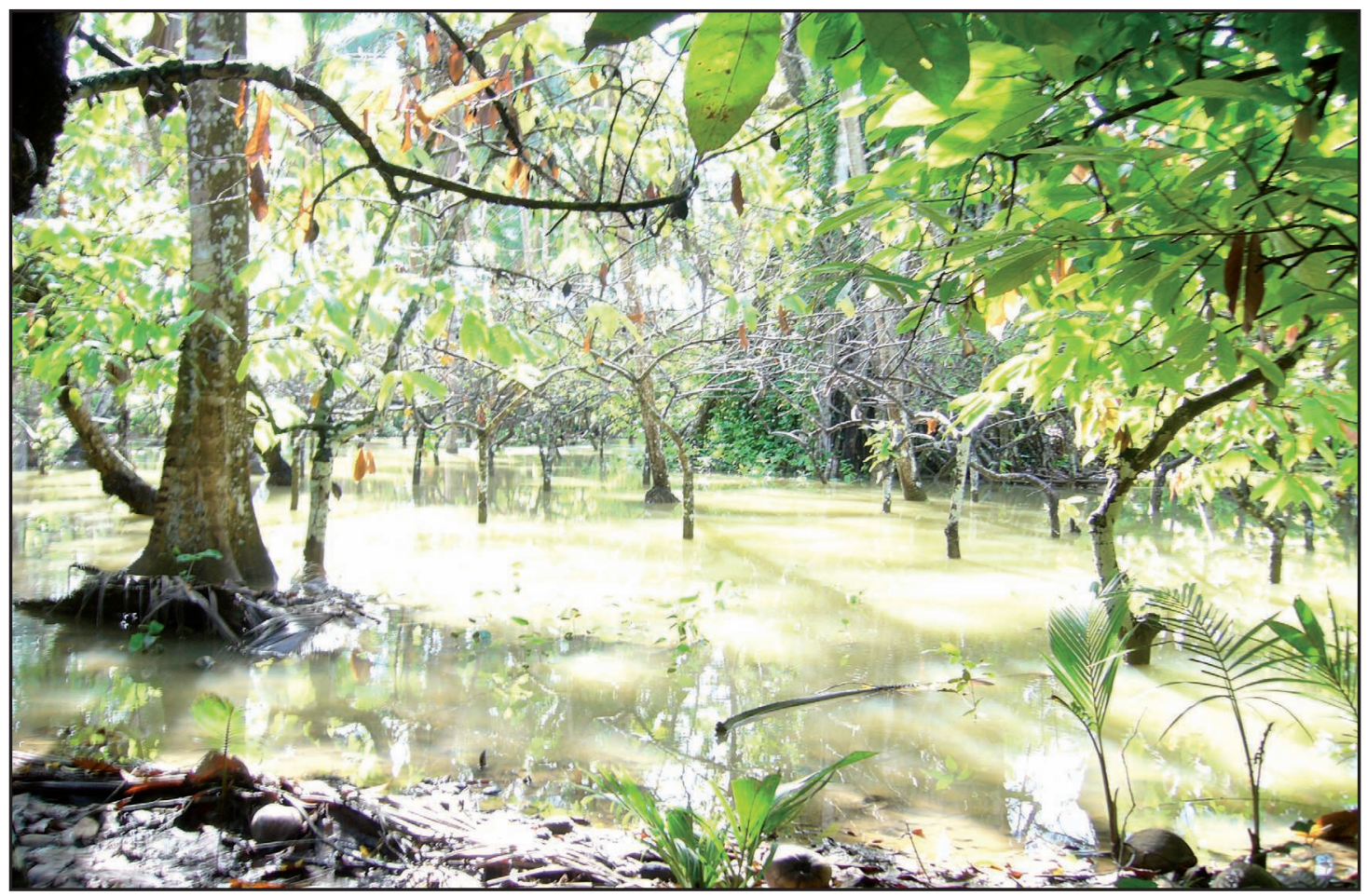


level of rainwater raised the level of water in the dam. The threat was already highlighted in the report by Dunkerley and Hallam in 1997 and the Saki case mentioned above. The government refused to issue the de-watering licence because waste water recycling and treatment plant was not working (sIBC, 24 April 2013). They instead asked the company to repair the system and treat the water before the application can be considered. It was later revealed in a report produced by three Solomon Islands scientists and communicated by the minister that:

«the rise in the water level of the Gold Ridge tailings dam is not due to rainwater but the company's mine wastes.» (Rakai, 2013)

The state therefore asked the company to repair the recycling and treatment plant after the report. In previous incidents, company put together scientific papers and evidence to support their cause while the ordinary people whose lives are affected remained at the mercy of the state and company enforced through a legal system operating on the bases of formal property rights and lack of a precautionary criterion as a sustainability principle.

\section{Experiences in relocation villages}

Since the mining of Gold Ridge was organisationally globalised, negotiations on compensation payments and relocating and resettling people occurred concurrently. The mining resulted in the resettlement of people away from their original homes. A total of 120 families had to be relocated to give way for the gold mine. As it turned out, 95 families were relocated to a government land (449 hectares) at Lungga while 25 families were resettled at Obo Obo, also known as Jericho village or Road Head (Obo Obo Men, 4 July 2007). These families were moved from their original localities, an environment that is typical of Solomon Islands highlands without mosquitoes to the Lunga area that is infested with malaria mosquitoes. The 95 families were so far from the river and mining area that gold panning is no longer a livelihood option. Moreover, the types of houses they now have to live in are different from those they were used to. They were moved to permanent and larger villages compared to their original lifestyle of shifting around in the same area and in the process build new homes.

Interviewees proudly told me that the people in the Obo Obo relocation village are better off. Before the mining only one person owned a permanent house but now all 25 families have permanent homes. They also claimed that:
«Lunga and Obo Obo are better off but Taotaona people accepted cash so they "ate" it all up (i.e. spent it all without building their homes). Obo Obo villagers were given SI\$20,000 each to build their own homes while Lunga villagers were built houses costing SI\$25,000 by the company.»

The houses were bigger and better equipped at Obo Obo compared to those built at Lunga. This is the usual story of people where mineral extraction and subsequent compensations and royalties are paid. Among the Ipilli people who «hosts» the Porgera mine PNG for instance, the influx of benefits also resulted in changed lifestyles but also with social disorders like increased domestic violence and drunken sprees in urban centres. Moreover, most of their money were spent on store-bought foodstuff like tinned fish and rice and on big budget items like pick-up trucks (Golub, 2006: 269). Figure 4 below gives an indication of the types of buildings built at the Obo Obo relocation village by villagers themselves with materials costs borne by the company.

Despite the modern corrugated iron homes, moving these people into permanent communities close to each other meant that there are serious health and hygiene considerations. It could be confidently argued from observation that the people of the mining area are used to living in smaller hamlets and move around frequently in the search for gold. However, their relocation to a permanent village, with permanent building posed health and hygiene concerns. The importance of pigs in status building and the local area's «Lou» feasts saw the breeding of pigs everywhere in the village which also raised concerns for health and hygiene in the community. All workshops held in the village recognised this weakness. However, they all blamed village leadership weakness as a cause of lack of village cleanliness controls without taking the initiative to tackle it. The most notable issue in relation to migration, movement and resettlement is the tension it brought about. This is more so for the relocation village at Lunga than Obo Obo. The settlers from Gold Ridge and the people of the areas in which they were being resettled (Belaha/ Malango) share the same language, kastom and most share membership in the same «line» or clan. Indeed, the original inhabitants receive cash benefits from their relatives and trustees of the Gold Ridge Mine and many young people of Belaha and Malango were employed by the mining company. Despite these commonalities and links, resettlement resulted in disagreements and conflicts with host communities. Stewart and Strathern (2005) claimed that domination or subjection within new environments is a common theme of diasporas in the Pacific islands through history. They stated that: 


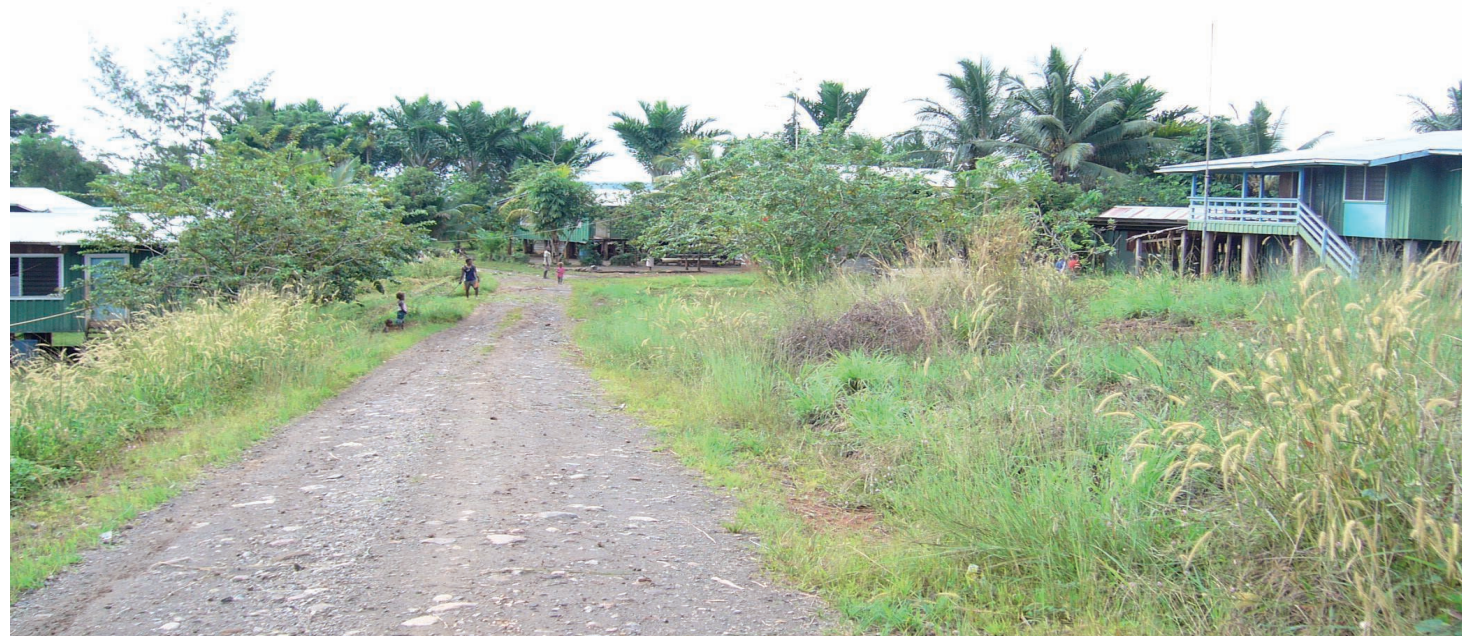

Figure 4. - Houses at Obo Obo relocation village (2007, picture Gordon Leua Nanau)

«[m]emory, history, and the emotions are all involved in the construction of cultural selves in new places.» (Stewart and Strathern, 2005: 206)

People relocating to Lunga faced similar resentments from Belaha people. This was seen through occasional brawls and arguments. This came to its peak during the country's civil uprising that forced those who resettled at Lunga to return their original homes for security reasons. The Belaha people took the opportunity to damage homes vacated by their wantoks. Chief Manegulai put it succinctly:

«They did not respect people from Belaha. Belaha people also disliked Gold Ridge people. After the tensions, they did not ask us but removed and sold our houses. Moro people ${ }^{6}$ did not respect other people of Guadalcanal (they associate Moro as God). Had they understood this, and we reconciled things would have improved.» (Mangulai, pers. com., 4 July 2007)

The important point to note is that, movement, settlement and migration is a critical factor for social instability in the Solomon Islands. The Gold Ridge settlers experience showed that it is more of an overarching issue and should not be based entirely on inter-wantok antagonisms and assessments. The relocation villages and experiences with host relatives and wantoks had helped us understand this issue a bit more. Intra-wantok relationships through a share of royalties cannot compensate relatives to happily accept «displaced» people. As can be seen from the historical context outlined above, mining in the Solomon Islands is only a small part of the tensions that has a longer history before the mine was opened.

It should be noted that on resumption of operations at the mine, those who were resettled at Lunga refused to return there because of the problems explained. They instead opted for the company to company to build two alternative relocation villages closer to their original at Gold Ridge but outside the mine lease. A total of 287 houses were built in these two relocation settlements and people moved into them in 2011 and 2012 (Godfrey, Battista et al., 2011: 591). It is still too early to assess the experiences of residents in these new villages. One thing that is eminently clear though is the difficulty of accessing water for day to day use. Currently, the company hire water tankers to deliver water to all these houses on a daily basis. It is an expensive exercise and one that needs attention.

\section{Employment opportunities and frustrations}

The lifestyle of the "displaced» villagers before and after being resettled was that of dependence on gold panning, processed food and very limited subsistence food gardening. As such, the Obo Obo people had to look for alternative jobs within the mining company or return to the panning region for occasional panning to keep up their livelihood needs. The level of formal education there is low

6. A reference to members of the "Gaena'alu Movement» that is influential in South and Central Guadalcanal. The movement promotes the idea of development that respects and safeguards their local way of life and organization (i.e. kastom). 
and people there openly acknowledged this deficiency. Resettlements resulted in parents quickly realising the importance of formal education. Children were actually progressing to high schools since relocated to the Lunga area but the Guadalcanal tensions put an end to this slow but determined progress (Obo Obo Men, 4 July 2007). To survive in their new settlements, the locals would need formal academic qualifications and skills to compete for jobs in the mine despite the hypothetical allocation of $80 \%$ of jobs for landowners. In one of his media releases prior to the opening of the mine, GRML's chief executive, estimated that 400 to 500 jobs will be created once the company fully operates but acknowledging that $80 \%$ of these would be for Gold Ridge landowners. $\mathrm{He}$ reported that in early 2007, they were only employing around 205 locals at the mine site and the Head Office (Mamu, 2007: 1). Unfortunately, the mine requires technical skills gained through formal education of which the local people of Gold Ridge neglected for years. Youths at Obo Obo confirmed that employment for them is lacking due to very scarce education qualifications and skills relevant for company employment.

Consequently, local people there are only employed in areas like field service, security, environment, and manual work. Only catering was given to the community as it is included in a MOU with the company (Obo Obo Youths, 5 July 2007). Note that women were unable to do most of the jobs in the mine because of gendered demarcated roles on Guadalcanal. For instance, providing security or driving heavy mining machines are regarded a man's job, although this is slowly changing. Moreover, women of Obo Obo were previously not encouraged to attend school. The women of the surrounding community were given the opportunity to cook for workers working on the mine site but these are short term employment opportunities, where women organize themselves in groups for a period of several weeks before another group takes over. Locals, particularly women and youths were not accessing mining jobs as they lacked formal education, thus, distant mineral poor villages and provinces took advantage of office and other technical jobs.

The relocated population were dependent on food from shops. Those who still have access to gold panning outside of the lease area pride themselves with their reliance on processed food and their desire for such foodstuff compared to local diets. On the day I was interviewing one of the principal landowners at Magazine settlement, loads of trucks were unloading foodstuff for a local trade store. These included sugar, rice, noodles, salt, canned food and alcohol. I also witnessed people carrying cartons and bags of processed foodstuff in their various makeshift houses. My host explained that most of these people deposited their gold with the store owner and as soon as food stuff from Honiara got in, they collected these from the shop based on the value of gold deposited. He further claimed that people of Gold Ridge area spent their money on beer and food as they rarely make food gardens and that the children are now more interested in processed foodstuff.

These people previously relied almost entirely on monies from alluvial gold panning to support their daily needs food supplies. The (re)establishment of the mine meant that they lose out on their means of income and would therefore look at alternative sources apart from the quarterly royalty payments received by the 16 «lines». The mining agreement realised this problem so deliberately included a provision that decorated the agreement. It says:

«GRLM may, in its absolute discretion, permit the continuation of traditional gold panning outside the Mining Lease in certain circumstances and subject to legal, safety and health and environmental requirements and may provide assistance to traditional gold panners with gold smelting and the sale of panned gold. Any such assistance will be subject to negotiation between GRML and the persons concerned.» (GRML and GRCLAC, 2006: 7)

This looks good on paper but has never been permitted.

The need for formal education and employment are becoming more visible as people now have to look for alternative sources of income. As indicated elsewhere in this paper, the workshops for this research saw lack of education as negatively impacting their new lifestyle. They pointed out that landowners are only employed in areas like field labourers, security guards, environment manual workers and a bit of catering given to the Obo Obo community as part of their understanding with the company (Men's Group, 4 July 2007). The emphasis on formal education is also indicated by the establishment of a kindergarten by the villagers in a community hall built with assistance from the mining company. The community lamented that the Guadalcanal tensions put a halt to the progress made at the Lunga relocation village which saw a good number of their children attending secondary schools then. As that group of students was disturbed by the tensions and the new relocation villages have just been built, it will take time before their children are educated to a level where they can work at the mine. The point is royalties will not sustain the livelihoods of Obo Obo villagers in the long run and education for wage labour is an option that they now have to pursue.

Apart from the Gold Ridge Investment Limited (currently not operational), personal investment and savings are not visible or practiced in these 
relocation villages. Royalties are shared to members of the sixteen tribes and then people wait for the next royalty payments to mature. It is from this vantage point that livelihoods are not sustainable for the relocated population. Royalties are good for the time being but with the attitude and trend in which royalties were used, it is unsustainable and could become a lost opportunity as soon as the mine stops. This is because significant portions of royalties are used on consumption with little long term investment in both wantok group and individual levels. More importantly, males are controlling royalties paid to households with females at the receiving end of the cycle.

\section{Conclusion}

The above discussions are based on the experiences of local indigenous Guadalcanal populations who are hosts of and are directly displaced by the mining operations at Gold Ridge. The account touches on people's expectations, the benefits obtained from the mine, frustrations, and fears. Being the first mine in the country, among communities that have had previous gold panning experience, their stories could assist potential mines and host communities to be more strategic in the redistribution of mineral proceeds with commitment to improve people's livelihoods. More importantly, it provides the first narrative on mine/community/state relationships in the Solomon Islands.

The research question whether royalties from company activities could be agents for improving community livelihoods and discourage vulnerability, insecurity and instability must be answered. The bold answer would be «yes». Unfortunately, this potentially powerful agent for improved livelihoods cannot be prompted because of two basic reasons. First is the basic fact that the mining agreement was skewed in favour of the company. The mine agreement prescribed only $1.5 \%$ of the gross value of gold and silver produced from the mine as the mining lease to landowning groups. In fact $20 \%$ of this is paid to the Guadalcanal Provincial Government, an agent of the state. Even with the already small percentage of the gross value earmarked for local landowning groups, the provincial government, as an entity of the state also dips into it. Ultimately, the narrative is that the mining company and the state benefitting more financially from mineral resources supposedly own by landowning tribes in the area. A study that provided a comparative analysis of the company/state/ community nexus in four states is offered by Le Meur, Ballard et al., (2013). Second, the nonoperation of the landowners' business arm (GIL) and the lack of investment mentality on the part of landowning groups meant that long term improvements through investments are not very promising. Communities continue to look up to the company and the state for financial benefits and services. Without proper investments for future sustainable revenues after the mine, sustainable and improved livelihoods will remain a distant dream for such communities.

On the question of the impacts of royalty payments, various licence fees, and rents from extractive industries impacted on the lives of people at Obo Obo and Tumurora, certain observations were made. With the establishment of the mine, the inhabitants of the area formalised local institutions in an effort to deal with negotiations, thus the establishment of the Gold Ridge Landowners Council, the Gold Ridge Downstream Association, the Kolobisi Downstream Association and other similar groupings. It has also resulted in the appointment of trustees as owners of lands leased; a movement away from collective ownership of customary land by tribes as explained above. The expectations and redistribution of various payments from the mine also resulted in court challenges and disputes both with local and international «interested» parties. Royalties and the mine's infrastructure also meant that the livelihood patterns and activities of resettled communities also changed. For instance, resettlement increased the importance of formal education with the hopes for locals to secure company and state employment. The mine has therefore impacted the lifestyles and outlook of landowners to the extent that in the long term, they have to look at alternative livelihoods, away from royalties and gold panning.

Finally, how does modern democratic agreements and courts impact or safeguard local social capital and environment? The state and its institutions are involved in most aspects of establishing the mine. State institutions are also expected to monitor and safeguard the interests of all stakeholders in the mining sector. However, from the perceptions of local people, state institutions and laws mostly safeguard the interests of the investors and the state agents. Police officers, for instance, have always been called upon to open roadblocks set up by disgruntled landowners, even if their concerns are genuine and life-threatening. The requirement for scientific evidence to prove a point in court and recognition of trustees as legal owners of lands leased are huge contradictions from the perspective of local landowning groups. The various court cases highlighted in the article attest to this contradiction and is an under researched area that warrants more detailed assessment in the future. Such contradictions play a fundamental role in creating vulnerability, insecurity and instability in the minds and lives of people that host the mining lease area. 


\section{BIBLIOGRAPHY}

AlLen M. G., 2012. Informal formalisation in a hybrid property space:The case of smallholder oil palm production in Solomon Islands, Asia Pacific Viewpoint 15 (3), pp. 300-313.

ASG, 2007. Annual report for the year ended 30 June 2007, Queensland, Australian Solomon Gold.

-, 2008. Gold Ridge Gold Mine Guadalcanal, Solomon Islands Community Relations Management Action Plan 2008, Newcastle, Graham A Brown \& Associates.

Asia Miner (The), 2007. Gold Ridge brings shine back to Solomon Islands, The Asia Miner (retrieved 19 December 2007, from www. asiaminer.com).

Banks G., 2008. Understanding «resource» conflicts in Papua New Guinea, Asia Pacific Viewpoint 49 (1), pp. 23-34.

Bemuta Community Relocation CommitTEE, 2006. Bemuta Community Relocation Committee Submission, sIG \& GRM (when negotiating reopening).

BenNeTt J., 1987. Wealth of the Solomon Islands: a history of a Pacific archipelago, 1800-1978, Honolulu, University of Hawaii Press.

Callick R., 2005. Resource issues as a source of conflict, Pacific Economic Bulletin 20 (1), pp. 181-184.

Carter R., 2006. In Search of the Lost: The Modern Martyrs of Melanesia, Norwich, UK, Canterbury Press.

Dunkerley D. L. and N. Hallam, 1997. Gold Ridge and Surroundings, Guadalcanal, Solomon Islands: An Environmental Assessment, Monash University, Australia.

Filer C., 1990. The Bougainville Rebellion, the Mining Industry and the Process of Social Disintergration in Papua New Guinea, Canberra Anthropology 13 (1), pp. 1-39.

—, 2006. Custom, Law and ideology in Papua New Guinea, The Asia Pacific Journal of Anthropology 7 (1), pp. 65-84.

Filer C. and M. Macintyre, 2006. Grass roots and deep holes: community responses to mining in Melanesia, The Contemporary Pacific 18 (2), pp. 215-231.

Gatu G. B., 1988 (24 March). Petition by indigenous people of Guadalcanal, P. Minister, Honiara.

Gegeo D. W. and K. A. Watson-Gegeo, 2002. Whose knowledge? Epistemological Collu- sions in Solomon Islands Community Development, The Contemporary Pacific 14 (2), pp. 377-409.

Godfrey S., J. Battista et al., 2011. Competent Persons' Report on Gold Ridge Gold Project, Guadalcanal, Solomon Islands, London, Allied Gold Limited.

Gold Ridge Community and Landowners Association Council (Grclac), 1996. Constitution of the Gold Ridge Community and Landowners Association Nalakasia School, Malango, Central Guadalcanal.

—, 2007 (24 April). GRCLAC submission to Solomon Islands Government, Honiara.

Golub A., 2006. Who is the "Original Affluent Society»? Ipili «Predatory Expansion» and the Porgera Gold Mine, Papua New Guinea, The Contemporary Pacific 18 (2), pp. 265-292.

GRML And GRCLAC, 2006 (31 May). Subsidiary Agreement: An Agreement between Gold Ridge Mining Ltd and the Gold Ridge Community and Landowners Association, Honiara.

Guadalcanal Provincial Assembly, 1998 (17 December). Demands by the bona fide and indigenous people of Guadalcanal (to the National Government), Honiara, Guadalcanal Province.

Guadalcanal Provincial Council, 1978 (October). A letter submitted to the Prime Minister, Prime Minister, Honiara.

High Court of Solomon Islands, 1997a (hearing 7 October, ruling 8 August). Willie Roni and Another v Ross Mining (SI) Ltd and Otrs, Civil Case No. 60 of 1997, Honiara.

—, 1997b (hearing 7 October, ruling 19 December). Maningelea $\mathrm{v}$ Ross Mining Ltd, Civil Case No. 168 of 1997, Honiara.

_, 1997c (hearing 7 October, ruling 19 December). Samuel Saki and Otrs v Ross Mining Ltd, Civil Case No. 60 of 1997, Honiara.

—, 1998 (hearing $1^{\text {St }}$ February 1999, judgement 10 June 1999). Ross Mining (SI) Ltd v Slatter and Gordon, Civil Case 230 of 1998 , Honiara.

Johnson I. and M. Powles (eds), 2012. New Flag Flying: Pacific Leadership, Wellington, Huia Publishers.

Le Meur P.-Y., C. Ballard, G. Banks, J.-M. Sourisseau, 2013. Two islands, four states: Comparing resource governance regimes in the Southwest Pacific, in J. Wiertz (ed.), Proceedings of the $2^{\text {nd }}$ International Conference on Social Responsibility in Mining (SRMining 
2013, Santiago, Chile), gecamin-smi, University of Queensland, pp. 191-199.

Maenu'u L. P., 1994. Solomon Islands: Recognising Traditional Landrights and Traditional Groups, in R. Crocombe and M. Meleisea (eds), Land Issues in the South Pacific, Christchurch, Macmillan Brown Center for Pacific Studies \& Institute of Pacific Studies, pp. 85-88.

Malango House of Chiefs, 2004 (11 September). Malango House of Chiefs Constitution, Bubulonga village.

Mamu M., 2007. More jobs for locals, Solomon Star Newspaper (retrieved 01 October 2008).

Namosuaia D., 2011 (17 June). Cyanide leak, Solomon Star, Honiara, Solomon Star Ltd.

—, 2011 (27 June). Fear grips communities over leaks, Solomon Star Newspaper.

Nanau G., 2008. Can a Theory of Insecure Globalisation explain Instability in the South Pacific? The Case of Solomon Islands, $\mathrm{PhD}$ School of International Development. Norwich, University of East Anglia.

—, 2011. The Wantok System as a Socio-economic and Political Network in Melanesia, Omnes: The Journal of Multicultural Society 12 (1), pp. 31-55.

O'Faircheallaigh C., 2008. Negotiating Cultural Heritage? Aboriginal-Mining Company Agreements in Australia, Development and Change 39 (1), pp. 25-51.

Osifelo E., 2013. Land issues dominate day one of PM's meet, Solomon Star Newspaper.

Proctor J. D., 1998. The Social Construction of Nature: Relativist Accusations, Pragmatist and Critical Realist Responses, Annals of the
Association of American Geographers 88 (3), pp. 352-376.

RakaI B., 2013. It's Mining Wastes, Solomon Star, Honiara, Solomon Star.

Solomon Islands Broadcasting CorporaTION, 2013. Premier thanked government for refusing licence to release contaminated water into river system.

Solomon Islands Government (sig), 2011. The Mines and Minerals (Royalties) Regulations 2011, Honiara, Solomon Islands National Parliament.

Solomon Islands Government (sig), Isatabu Freedom Movement (IFM) et al., 2001 (15 October). Townsville Peace Agreement. Townville Peace Conference, Townsville, Australia.

SOlOmon IsLands Government and THE Gold Ridge Community and Landowners Association, 1996 (4 October). Agreement Relating to the Development of the Gold Ridge Mine, Central Guadalcanal.

SOLOMON TIMES ONLINE, 2013. Landowners Demand SBD\$8 Million, Solomon Times Online.

St Barbara Limited, 2014. Gold Ridge, retrieved 12 January 2014 from http://www.stbarbara.com.au/our-operations/gold-ridge/.

Stewart P. J. and A. Strathern, 2005. Body and Mind on the Move: Emplacement, Displacement, and Trans-placement in Highlands Papua New Guinea, Asia Pacific Forum 27 (3), pp. 205-217.

Vaioleti T. M., 2006. Talanoa Research Methodology: A Developing Position in Pacific Research, Waikato Journal of Education 12, pp. 21-34. 